\begin{tabular}{l}
$\begin{array}{l}\text { A C T A I C H T H Y O L O G I C A } \\
\text { Vol. XX, Fasc. 1 }\end{array}$ \\
\hline
\end{tabular}

Marek K. JURKOWSKI

Environmental pollution

\title{
EFFECT OF THE DBS DETERGENT* ON OXYGEN CONCENTRATION IN WATER
}

\section{WPE YW DETERGENTU DBS* NA ZAWARTOŚĆ TLENU W WODZIE}

\author{
University of Gdańsk
}

Effect of DBS detergent on oxygen diffusion out of and into water with no or $9^{\circ} \% \mathrm{NaCl}$ was tested. Concentrations of detergent used were $5 ; 50$ and $250 \mathrm{mg} / 1$ SA. Oxygen content was measured after $24 \mathrm{~h}$ by the Winkler's methodd; in observations up to 10 days oxygen pressure was measured with Plastomed 305 apparatus. There was no direct effect of detergent present in water on its oxygen content no matter it there were carp juveniles or no fish at all.

\section{INTRODUCTION}

According to many communications it is quite clear for detergents to be toxic to organisms living in waters (Bardach, et al. 1965; Cronin and Flemer, 1967; Eisler, 1965; George, 1970; Granmo, 1971; Abel, 1974). A toxic effect of detergents on fishes was noted during suryeys on fish behaviour (Bardach et al., 1965; rorpela, 1969 as well as surveys of tissue enzymes e.g. in gills, serum or brain (Jurkowsli 1977; Lundhal, a Cabridence 1978; Jurkowski et al., 1979).

Aside its toxic effect on organisms living in water, detergents are irreplacebie as cleansers in households, industry (Anastasiu and Jelesocu, 1973) and also for crude oil lickeage removal (Smith, 1968) although some of detergents are more toxic for animals, than crude oil is (George, 1970).

High amounts of surface-active agents get, from rivers, into gulfs waters, presenting a serious risk for inhabiting organisms (Trewa et al. 1975; Gramno, 1971; Żmudziński,

\footnotetext{
* Sodium dodecylbenzenesulphonate (DBS)
} 
1983). Although recently production of detergents less toxic for water organism has been started (Swedmark et al., 1973) nevertheless "traditional" ones are to be used for many years, yet.

Among many data concentrating the toxic effect of surfactants, there are only few dealing with effect of physical agents on detergents toxicity; with few elder data suggesting detergents to decrease the oxygen content in water (Cronin and Flemer, 1967; Korpela, 1969). Our earlier results (Jurkowski, 1979) conducted on the perch fry, suggested the above to be a false statement, however it was found purposefull to test an effect of detergent on diffusion of oxygen into "fresh" and saline waters with and without organisms within these water.

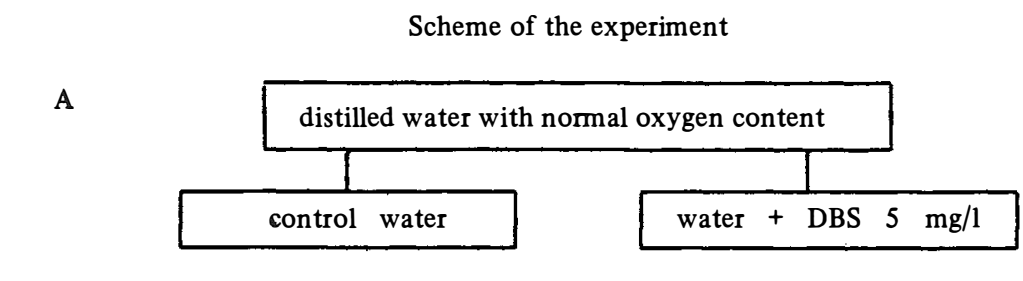

B

results in table 1

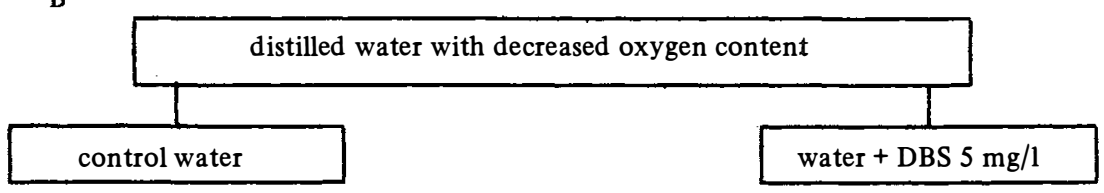

results in table 2

C

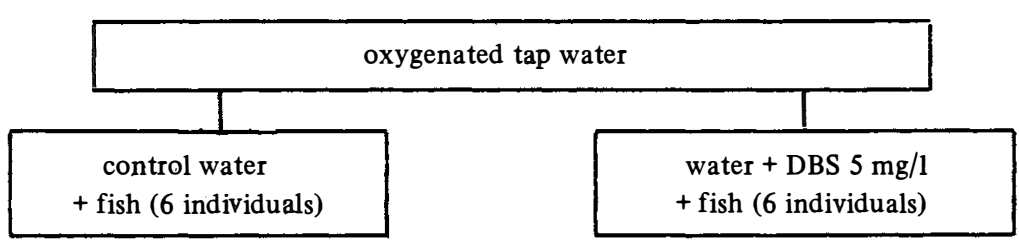

results in table 2

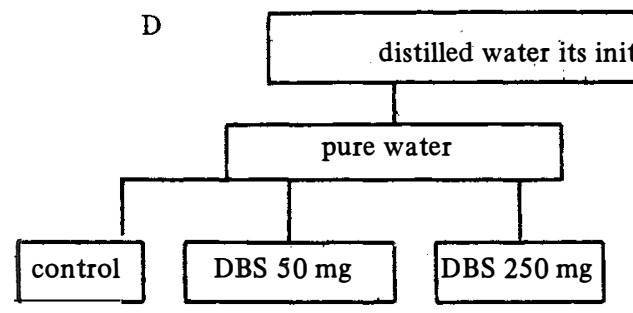

results in table 3

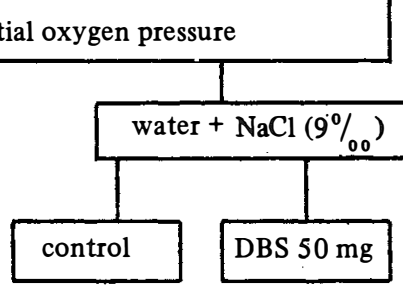

results in table 4

Fig. 1. Scheme of the experiment 
A rather common substract for production of many washing preparates in Poland is sodium dodecylbenzenesulphonate (DBS), toxic effect of which is well known (Jurkowski, 1977, Jurkowski et. al. 1979), that was why that detergent was chosen for the experiment.

\section{MATERIAL AND METHODS}

The experimental scheme is presented on Fig. 1. The DBS detergent was obtained from the Chemical Plant in Gdańsk. Fry of carp used had 20 to $50 \mathrm{~g}$ of weight. Oxygen concentration was measured by the Winkler's method (experiments including fishes as well as 24-h experiments with no fish). In the ten 24-hour experiments pressure of oxygen in water was measured with Plastomed 305 apparatus. All the reagents used were produced by the Polish Chemicals - pure for analysis. Experimental vessels were either 21 in volume and $154 \mathrm{~cm}^{2}$ in diameter (experiments with no fish in it) or 51 in volume and $576 \mathrm{~cm}^{2}$ in diameter (experiments with fishes).

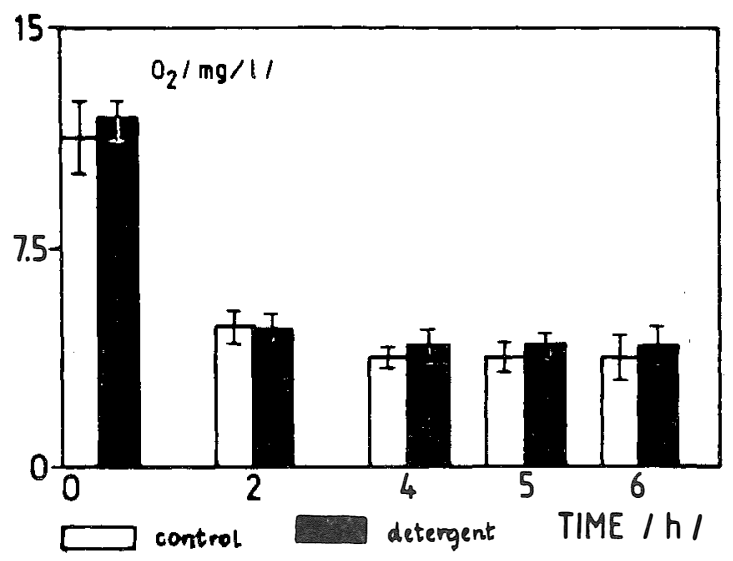

Fig. 2. Rate of oxygen drop in water with fishes

Fish fry was kept in settled, oxygenated tap water (Fig. 10), while other experiments were carried on in settled, distilled water (Fig. 1A and D) distilled water partially oxygen free (Fig. 1B) or in distilled water with $9 \mathrm{~g} \mathrm{NaCl} / 1$. Following concentrations of detergent were applied:

$5 \mathrm{mg} / 1 \mathrm{SA}$ - for fish and 24-hours experiments and

$50 \mathrm{mg} / \mathrm{l}$ and $250 \mathrm{mg} / \mathrm{l} \mathrm{Sa}$ - in ten - 24-hours observations.

Measures were taken after collecting water samples from the bottom, in three repetitions. Results presented represent average value \pm standard deviations. 


\section{RESULTS AND DISCUSSION}

According to Korpela's results (1969) there was $13.4 \mathrm{mg}$ of various detergents/1 of Helsinki municipal sewages, of which, after purification, $2 \mathrm{mg} / \mathrm{l}$ got into marine waters. In 1956, contamination of the USA rivers with detergents ranged from $0.1 \times 10^{-3}$ to $0.5 \times 10^{-3}$ $\mathrm{kg} / \mathrm{m}^{3}$ (Bardach et al., 1965) reaching $40 \times 10^{-3} \mathrm{~kg} / \mathrm{m}^{3}$ in 1974 (Abel, 1974). Due to the data for the Dead Vistula River, there were seasonal fluctuations in detergent contents; for example in 1975 , noted differences oscilated between $1.69 \times 10^{-3}$ and $2.64 \times 10^{-3}$ $\mathrm{kg} / \mathrm{m}^{3}$ (Drewa et al., 1975) Although there were no, more actual, data available, presumably since than, concentration of detergents haven't decreased, that was why doses of detergent applied in the experiments were relatively high and equal to 50 and $250 \mathrm{mg} / \mathrm{l}$ SA. Testing relations between an oxygen concentration and oil impurities in waters, Otremba and Kaniewski (1983) proved there to be one between oxygen content and an air-water contact surface with the oxygen decreasing rate being particularly fast within the first 10 days of the experiment (decrease in initial oxygen content by 50\%).

In the present experiments, beside the 24-hours ones (Tab. 1 and 2) the ten-days experiments were conducted, however, according to results (Tab. 3 and Tab. 4) no essential changes in an oxygen pressure were observed in waters, both, with and without $\mathrm{NaCl}$. Experiments were conducted in containers with a small air-water contact surface, as to get thicker layer of detergent on the surface, just to make an oxygen diffusion more difficult.

Table 1

\begin{tabular}{|c|c|c|}
\hline \multirow{2}{*}{$\begin{array}{c}\text { Time } \\
\text { (hours) }\end{array}$} & \multicolumn{2}{|c|}{$\begin{array}{c}\text { Oxygen content } \\
\text { (mg/l) }\end{array}$} \\
\cline { 2 - 3 } & control & detergent \\
\hline 0 & $11.6 \pm 0.7$ & $11.6 \pm 0.7$ \\
\hline 6 & $11.9 \pm 0.8$ & $12.2 \pm 0.8$ \\
\hline 24 & $11.5 \pm 1.2$ & $11.8 \pm 0.7$ \\
\hline
\end{tabular}

Table 2

\begin{tabular}{|c|c|c|}
\hline \multirow{2}{*}{$\begin{array}{c}\text { Time } \\
\text { (hours) }\end{array}$} & \multicolumn{2}{|c|}{$\begin{array}{c}\text { Oxygen content } \\
(\mathrm{mg} / \mathrm{l})\end{array}$} \\
\cline { 2 - 3 } & control & detergent \\
\hline 0 & $8.0 \pm 1.0$ & $8.0 \pm 1.0$ \\
\hline 24 & $10.7 \pm 1.1$ & $11.5 \pm 0.7$ \\
\hline
\end{tabular}




\begin{tabular}{|c|c|c|c|}
\hline \multirow{3}{*}{$\begin{array}{l}\text { Time } \\
\text { (hours) }\end{array}$} & \multicolumn{3}{|c|}{$\begin{array}{l}\text { Oxygen pressure } \\
(\mathrm{mm} \mathrm{Hg})\end{array}$} \\
\hline & \multirow{2}{*}{ control } & \multicolumn{2}{|c|}{ detergent } \\
\hline & & $50 \mathrm{mg} / 1 \mathrm{SA}$ & $250 \mathrm{mg} / 1 \mathrm{SA}$ \\
\hline 0 & $153 \pm 5.2$ & $153 \pm 5.2$ & $153 \pm 5.2$ \\
\hline 24 & $148 \pm 2.3$ & $149 \pm 5.0$ & $149 \pm 1.1$ \\
\hline 48 & $146 \pm 1.1$ & $140 \pm 5.4$ & $143 \pm 3.9$ \\
\hline 96 & $149 \pm 4.7$ & $150 \pm 2.2$ & $142 \pm 5.7$ \\
\hline 168 & $153 \pm 4.8$ & $155 \pm 1.1$ & $144 \pm 8.3$ \\
\hline 216 & $146 \pm 2.8$ & $152 \pm 4.3$ & $144 \pm 7.5$ \\
\hline 240 & $147 \pm 3.7$ & $142 \pm 4.6$ & $138 \pm 7.6$ \\
\hline
\end{tabular}

Table 4

Effect detergent on oxygen content in saline water $(9 \mathrm{~g} \mathrm{NaCl} / 1)$

\begin{tabular}{|c|c|c|c|}
\hline \multirow{2}{*}{$\begin{array}{c}\text { Time } \\
\text { (other) }\end{array}$} & \multirow{2}{*}{$\begin{array}{c}\text { Oxygen pressure } \\
\text { (mm Hg) }\end{array}$} \\
\cline { 2 - 4 } & control & $50 \mathrm{mg} / \mathrm{l} \mathrm{SA}$ & $250 \mathrm{mg} / 1 \mathrm{SA}$ \\
\hline 0 & $147 \pm 2.6$ & $154 \pm 5.5$ & $152 \pm 3.2$ \\
\hline 24 & $145 \pm 1.7$ & $152 \pm 4.2$ & $150 \pm 4.3$ \\
\hline 48 & $138 \pm 5.3$ & $145 \pm 3.7$ & $122 \pm 6.8$ \\
\hline 96 & $150 \pm 2.8$ & $150 \pm 5.2$ & $136 \pm 5.6$ \\
\hline 168 & $154 \pm 2.3$ & $151 \pm 2.2$ & $143 \pm 5.7$ \\
\hline 216 & $146 \pm 3.7$ & $151 \pm 4.3$ & $144 \pm 3.9$ \\
\hline 240 & $135 \pm 3.2$ & $147 \pm 5.4$ & $130 \pm 6.9$ \\
\hline
\end{tabular}


Sensitivity of fishes and other water organisms towards detergents depends, in between, on type of deteregent, its concentration and organism species (Thatcher, 1966, George, 1970, Swedemark et al., 1971) itself. Toxicity of detergents depends, to a high degree, on its chemical structure, water $\mathrm{pH}$ and hardness, oxygen concentration and temperature of water (Eisler, 1965; Hohanson and Smith, 1971). In the experiments with fishes, oxygen decreasing rate, in both containers was alike (Fig. 2), however fishes within the control container survived while these- within the container with detergent started to die. (Experiment ended when three fishes died in water with detergent. Obtained results indicated the direct cause of the fishes death was other then lack of oxygen in the water. Simmilar results were obtained in experiments with no fish. Yet indirect effect of detergent on oxygen concentration in water, through eutrophication process, for example, can't be excluded. (Cronin and Flemer, 1967; Zbytniewski et al., 1975). Observations of Kaniewski and Otremba (1983), however, concerning pollution with oil-derivatives, proved there to be an increase in oxygen concentration in polluted waters.

According to the obtained results it can be stated the tested detergent has no direct effect on the oxygen concentration in water.

\section{ACKNOWLEDGES}

I wish to thank W. Nieroda, the medicine doctor, from the Physiology Department at the Medical Academy in Gdańsk, for measures of the oxygen pressure in water samples taken with the Plastomed 305 apparatus.

\section{REFERENCES}

Abel P.D., 1974: Toxicity of synthetic detergents to fish and aquatic invertobrates. J. Fish. Biol. 6: 279-298.

Anastasiu S., E. Jelescu, 1973: Środki powierzchniowe czynne. Surfactants W.N.T., Warszawa: 11-20.

Bardach J.E., M. Fujia, A. Holl, 1965: Detergents effects on the chemical senses of the fish Ictalurus natalis (Le Sueur). Science 148: 1605-1607.

Cronin L.E., D.A. Flemer, 1967: Energy transfer and pollution in Pollution and marine ecology. Ed. Olson T.A., and Burges F.J., Interscience Publishers, New York-London-Sydney: 171-192.

Drewa G., Z. Zbytniewslk, F. Pautsch, 1975: Seasonal changes in the level of detergents in the brackish water of the Dead Vistula and Bay of Gdańsk. Morentutkimuslait Julk. (Harforskininsints Skr.) 239: 105-108.

Eisler R., 1965: Some effects of a synthettc detergent on estuarine fishes. Trans. Am. Fish. Soc. 94: 26-31.

George J.D., 1979: Sublethal effects on living organisms. Mar. Pollut. Bull. 27: 107-109.

Granmo A., 1971: Biological effects of surface active agents on marine animals. Mar. Biol. 9: 183-201.

Hokanson K.E.F., L.L. Smith, 1971: Some factors influencing the toxicity of linear alkylobenzene sulphonate (LAS) to the blugill. Trans. Am. Fish. Soc. 100: 1-12. 
Jurkowski M.K., 1977: Effect of DBS detergent on activity of some enzymes of young carp brain, gills and serum. Acta Ichthyol. Pisc. VII. Fasc. 2: 47-53.

Jurkowski M.K., M. Stachowiak, J.W. Białowąs, 1979: Effects of certain stress situations and DBS on acetylcholintransferase acetylocholinesterase and monoaminoxidase activitles in various regions of brain of juvenile carp. Acta Ichthyol. Pisc. IX. Fasc. 2: 21-29.

Jurkowski M.K., 1979: The effect of DBS on survival of juvenile perch in relation to certain physical factors. Acta Ich thyol. Pisc. IX. Fasc. 2: 55-61.

Kaniewski E., Z. Otremba, 1983: The effect of seasonal changes of oil pollution on the oxygen concentration in water of the Gulf of Gdańsk. Studia i Materiały Oceanolog. 41: 167-180.

Korpela T., 1969: The effect of synthetic detergents on fish stock. Eripainos Vesitalous 5: 1-4.

Lundhal P., R. Cabridence, 1978: Molecular structure-biological properties relationship in anionic active agents. Wat. Res. 12: 25-30.

Otremba Z., E. Kaniewșki, 1983: Wpływ wielkości powierzchni kontaktu olej-woda na szybkość zmiany stężenia tlenu w wodzie zanieczyszczonej zemuglowanym olejem. Effect of the oil-water contact surface size on the changes rate in oxygen concentration, in waters polluted with emulsified oil. Studia i Materiały Oceanolog. 41:153-166.

Smith J.E., 1968: "Torrey Canyon" pollution and marine life. Mar. Biol. Ass. of U.K., Cambridge Univ. Press. Ed Gen. Smith J.E.

Swedemark M., B. Braaten , E. Emmanuelsson, A. Granmo, 1971: Biological effects of surface active agents on marine animals. Mar. Biol 9: 183-201.

Swedemark M., A. Granmo, S. Kollberg, 1973: Effects of oil dispersants and oil emulsions on marine animals. Wat. Res. 7: 1649-1672.

Thatcher T.O., 1966: The comparative lethal toxicity of a mixture of hard ABS detergent products to eleven species of fishes. Air Wat. Pollut. Int. J. 10: 585-590.

Zbytniewski Z., G. Drewa, F. Pautsch, 1975: Effect of detergents and phosphogypsum on the oxygen and chlorophyl $\mathbf{A}$ levels and on the dry weight of the residue of brackish water under laboratory conditions. Merentutkimuslait Julk. (Harsforskininginst Skr.) 293: 100-104.

Żmudziński L., 1983: Pollution problems of Baltic Sea. Pol. Ecol. Stud. 9: 397-415.

Translated: Dr E. Daczkowska-Kozon

Marek K. Jurkowski

\section{WPŁYW DETERGENTU DBS* NA ZAWARTOŚĆ TLENU W WODZIE}

\section{STRESZCZENIE}

Wykonano oznaczenie tlenu metodą Winklera w wodzie $z$ dodatkiem detergentu DBS po 24 godzinach, w eksperymencie $z$ narybkiem karpia oraz bez rỷb. Użyto detergent w stężeniu $5 \mathrm{mg} / \mathrm{l}$ SA. Stwierdzono brak różnic $w$ zawartości tlenu w wodzie bez detergentu i z detergentem, jakkolwiek w tej ostatniej ryby zaczęły snąć po 5 godzinach doświadczenia. Wykonano również eksperymenty bez ryb z dużymi stężeniami detergentu 50 i $250 \mathrm{mg} / 1$ SA prowadząc pomiary prężności tlenu aparatem Plastomed 305 do 10 dób w wodzie bez isoli i zasolonej w ilości $9 \%$.Takze w tych doświadczeniach nie stwierdzono istotnych różnic w zawartości tlenu w badanej wodzie.

Uzyskane rezultaty pozwalają stwierdzić, iż obecność detergentu w wodzie nie wpływa w sposób bezpośredni na zawartość w niej tlenu.

* dodecylobezenosulfonian sodowy 
Author's address:

Received: 1989.03.20

Dr Marek K. Jurkowski

Katedra Fizjologii Zwierząt

Uniwersytet Gdański

ul. Kładki 24

80-922 Gdańsk, Polska (Poland) 